Nov The no

Manchester

Spenser

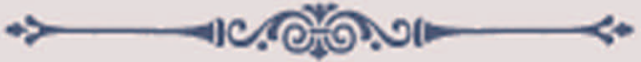

\title{
European
}

\section{erotic romance}

Philhellene Protestantism,

Renaissance translation and English literary politics

$\leadsto$ - 


\section{European erotic romance}

\section{MANCHESTER 1824}

Manchester University Press 


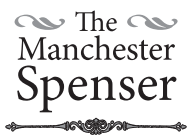

The Manchester Spenser is a monograph and text series devoted to historical and textual approaches to Edmund Spenser - to his life, times, places, works and contemporaries.

A growing body of work in Spenser and Renaissance studies, fresh with confidence and curiosity and based on solid historical research, is being written in response to a general sense that our ability to interpret texts is becoming limited without the excavation of further knowledge. So the importance of research in nearby disciplines is quickly being recognised, and interest renewed: history, archaeology, religious or theological history, book history, translation, lexicography, commentary and glossary - these require treatment for and by students of Spenser.

The Manchester Spenser, to feed, foster and build on these refreshed attitudes, aims to publish reference tools, critical, historical, biographical and archaeological monographs on or related to Spenser, from several disciplines, and to publish editions of primary sources and classroom texts of a more wide-ranging scope.

The Manchester Spenser consists of work with stamina, high standards of scholarship and research, adroit handling of evidence, rigour of argument, exposition and documentation. The series will encourage and assist research into, and develop the readership of, one of the richest and most complex writers of the early modern period.

General Editor J. B. Lethbridge

Editorial Board Helen Cooper, Thomas Herron, Carol V. Kaske, James C. Nohrnberg \& Brian Vickers

Also available

Shakespeare and Spenser: Attractive opposites J. B. Lethbridge (ed.) 


\title{
European erotic romance
}

\author{
Philhellene Protestantism, \\ Renaissance translation \\ and English literary politics
}

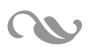

VICTOR SKRETKOWICZ

Manchester University Press

Manchester 
Copyright $\odot$ Victor Skretkowicz 2010

The right of Victor Skretkowicz to be identified as the author of this work has been asserted by him in accordance with the Copyright, Designs and Patents Act 1988.

Published by Manchester University Press

Altrincham Street, Manchester M1 7JA

www.manchesteruniversitypress.co.uk

British Library Cataloguing-in-Publication Data

A catalogue record for this book is available from the British Library

Library of Congress Cataloging-in-Publication Data applied for

ISBN 9780719079702 hardback

First published 2010

The publisher has no responsibility for the persistence or accuracy of URLs for any external or third-party internet websites referred to in this book, and does not guarantee that any content on such websites is, or will remain, accurate or appropriate.

Typeset in Minion by

Koinonia, Manchester 